\title{
PENGELOLAAN PEMBIAYAAN PENDIDIKAN DI INDONESIA
}

\author{
AULIA RISKI \\ Universitas Negeri Padang \\ auliariski45@gmail.com
}

\begin{abstract}
Dalam (Undang-undang tentang Sistem Pendidikan Nasional No. 20, tahun 2003) dijelaskan bahwa dana pendidikan adalah seluruh pengeluaran yang berupa sumber daya (input) baik berupa barang maupun berupa uang yang ditujukan untuk menunjang kegiatan proses belajar mengajar. Pengelolaan dana pendidikan adalah proses perencanaan, pelaksanaan, dan evaluasi pengalokasian biaya untuk program dan kegiatan pendidikan karakter yang tertuang dalam Rencana Kerja Sekolah (RKS) dan Rencana Kegiatan Anggaran Sekolah (RKAS). Menurut sumbernya biaya pendidikan dapat digolongkan menjadi 4 jenis yaitu: a) biaya pendidikan dari pemerintah, b) biaya pendidikan dari masyarakat orang tua/wali kelas, c) biaya pendidikan dari masyarakat bukan orang tua/wali siswa missal sponsor dari lembaga keuangan dan perusahaan, 4) lembaga pendidikan itu sendiri.
\end{abstract}

Keywords : pengelolaan; biaya;, sekolahr; pendidikan.

\section{PENDAHULUAN}

Pendidikan sebagai salah satu elemen yang sangat penting dalam mencetak generasi penerus bangsa juga masih jauh dari yang diharapkan. Seharusnya pendidikan merupakan hak bagi seluruh rakyat Indonesia sebagaimana tercantum dalam Pembukaan UUD R.I Tahun 1945 bahwa tujuan Negara yaitu "mencerdaskan kehidupan bangsa". Hal ini memiliki konsekuensi bahwa Negara harus menyelenggarakan dan memfasilitasi seluruh rakyat Indonesia untuk memperoleh pendidikan yang layak bagi kehidupannya. Pembiayaan pendidikan merupakan komponen yang esensial dan tidak dapat terpisahkan dalam penyelenggaraan proses belajar-mengajar. Dalam rangka pembentukan potensi sumber daya manusia (SDM), penggunaan anggaran pendidikan yang efektif dan efisien diharapkan dapat menghasilkan SDM yang tepat guna dan berhasil guna.

Suatu sekolah untuk memiliki tenaga kependidikan yang berkualitas dengan jumlah yang mencukupi kebutuhan memerlukan biaya rekrutmen, penempatan, penggajian, pendidikan dan latihan, sertamutasi. Dalam usaha pengadaan sarana dan prasarana untuk menunjang proses pembelajaran tentu saja diperlukan dana yang tidak sedikit, bahkan setelah diadakan maka diperlukan dana untuk perawatan, pemeliharaan, dan pendayagunaannya. Meskipun ada tenaga, ada sarana dan prasarana, untuk memanfaatkan dan mendayagunakan secara optimal perlu biaya operasional baik untuk bahan dan ATK habis pakai, biaya pemeliharaan, maupun pengembangan personil agar menguasai kompetensi yang dipersyaratkan. Dari uraian di atas jelas bahwa untuk penyelenggaraan pendidikan di sekolah termasuk di SMP perlubiaya, perludana, paling tidak memenuhi pembiayaan untuk memberikan standar pelayanan minimal. Biaya pendidikan merupakan komponen sangat penting dalam penyelenggar aan pendidikan. Dapat dikatakan bahwa proses pendidikan tidak dapat berjalan tanpa dukungan biaya. Dalam konteks perencaaan pendidikan, pemahaman tentang anatomi dan problematik pembiayaan pendidik anamat diperlukan. Berdasarkan pemahaman ini dapat dikembangkan kebijakan pembiayaan pendidikan yang lebih tepat dan adil serta mengarah pada 
pencapaian tujuan pendidikan, baik tujuan yang bersifat kuantitatif maupun kualitatif.

Pengelolaan berasal dari kata manajemen (administrasi). Manajemen berasal dari kata to manage yang berarti mengatur, mengurus atau mengelola. Banyak definisi yang telah dikemukakan oleh para ahli. Yang keseluruhannya mengarah pada pengertian bahwa manajemen merupakan sebuah seni dan ilmu perencanaan, pengorganisasian, penyusunan, pengarahan, dan pengawasan sumber daya untuk mencapai tujuan yang sudah di tetapkan. Manajemen menurut Udaya (1995) memberikan rumusan bahwa manajemen yaitu: Proses untuk mencapai tujuan tujuan organisasi dengan melakukan kegiatan dari empat fungsi utama yaitu merencanakan (planning), mengorganisasi (organizing), memimpin (leading), dan mengendalikan (controlling). Dengan demikian, manajemen adalah sebuah kegiatan yang berkesinambungan. Manajemen pendidikan merupakan rangkaian kegiatan atau keseluruhan proses pengendalian usaha kerja sama sejumlah orang untuk mencapai tujuan pendidikan secara berencana dan sistematis yang diselenggarakan pada lingkungan tertentu, terutama dalam bentuk lembaga pendidikan yang bersifat formal.

Sedangkan pembiayaan dapat di definisikan sebagai kemampuan interval sistem pendidikaan untuk mengelola dana pendidikan dengan efisien. Pembiayaan muncul sebagai input yang digunakan untuk setiap kegiatan pendidikan. Tidak hanya terkait dengan mengetahui ataupun menganalisa sumber dana, melainkan juga bagaimana cara penggunaan dana yang efektif dan efisien. Maka dapat didefinisikan bahwa manajemen pembiayaan pendidikan adalah segenap kegiatan yang berkenaan dengan penataan sumber, penggunaan, dan pertanggungjawaban dana pendidikan di sekolah atau lembaga pendidikan. Keungan dan pembiayaan merupakan salah satu sumber daya yang secara langsung menunjang efektivitas dan efisiensi pengelolaan pendidikan. Dalam peng implementasiannya sangat menuntut kemampuan untuk merencanakan, melaksanakan, dan mengevaluasi serta mempertanggungjawabkan pengelolaan dana secara transparan kepada masyarakat dan pemerintah. Keuangan dan pembiayaaan sangat menentukan ketercapaian tujuan pendidikan yang memerlukan sejumlah investasi dari anggaran pemerintah dan dana masyarakat. Investasi tersebut harus dikelola secara efektif dan efisien serta diarahkan langsung terhadap pencapaian tujuan. Hal ini merupakan kegiatan manajemen keuangan yang mengatur penerimaan, pengalokasian, dan pertanggungjawaban keuangan untuk menunjang pelaksanaan program pengajaran. Beberapa kegiatan yang ada dalam pengelolaan biaya pendidikan mencakup tiga hal, yakni: Perencanaan biaya pendidikan, Pelaksanaan pengelolaan biaya pendidikan, dan evaluasi pengelolaan biaya pendidikan.

Sekolah merupakan sistem yang terdiri atas serangkaian komponen yang saling terkait, dan membutuhkan masukan dari lingkungan untuk melakukan proses transformasi serta mengeluarkan hasil. Kebutuhan terhadap masukan dan pengeluaran sudah menjadi hal yang tidak dapat dipisahkan lagi. Hal tersebut disebabkan karena adanya ketergantungan antara sekolah dengan masyarakat serta lingkungannya. Masukan terhadaop sistem sekolah mencakup perangkat lunak, keras, dan manusia yang selaras dengan perkembangan lingkungan. Hal inilah yang akan memberikan konsekuensi dalam proses transformasi sistem sesuai denan tuntutan lingkungan terhadap keluaran.

\section{PEMBAHASAN}

\section{Pengelolaan Pembiayaan Pendidikan}

\section{a. Pengertian Pembiayaan}

Keuangan dan pembiayaan merupakan salah satu sumber daya yang secara langsung menunjang efektivitas dan efisiensi pengelolaan pendidikan. Dalam penyelenggaraan pendidikan, keuangan dan pembiayaan merupakan potensi yang sangat menentukan dan merupakan bagian yang tak terpisahkan dalam kajian manajemen pendidikan.

Definisi biaya menurut Supriyono biaya adalah pengorbanan ekonomis yang dibuat untuk memperoleh barang atau jasa. Secara bahasa, biaya (cost) dapat diartikan sebagai pengeluaran, dalam istilah ekonomi biaya pengeluaran dapat berupa 
uang atau bentuk moneter lainnya. (Dedi Supriadi, 2004) dalam bukunya mendefinisikan biaya sebagai semua jenis pengeluaran yang berkenaan dengan penyelenggaraan pendidikan baik dalam bentuk uang, barang, dan tenaga (yang dapat dihargakan dengan uang).

Menurut Hasbullah Pembiayaan sekolah adalah kegiatan mendapatkan biaya serta mengelola anggaran pendapatan dan belanja pendidikan. 3 Biaya dalam pengertian ini yaitu jenis pengeluaran baik dalam bentuk barang maupun tenaga untuk kepentingan penyelenggaraan pendidikan. Pembiayaan pendidikan pada dasarnya adalah menitik beratkan upaya pendistribusian benefit pendidikan dan beban yang harus ditanggung masyarakat. Unsur biaya adalah hal yang menentukan dalam mekanisme penganggaran. Penentuan biaya sangat mempengaruhi tingkat efisiensi dan efektivitas kegiatan lembaga/organisasi dalam mencapai tujuan tertentu.

Menurut (Domai, 2010) Pembiayaan pendidikan tidak lepas dari persoalan "ekonomi pendidikan". Bahkan, secara tegas Mark Blaugh mengemukakan bahwa "the economics of education is a branch of economics". Jadi, dapat dikatakan menurut pandangan ini bahwa pada dasarnya pembiayaan pendidikan merupakan bagian atau cabang dari ilmu ekonomi. Sebab, pembiayaan pendidikan menurut Blaugh sebagai the costing and financing of school places, yaitu bagian dari permasalahan ekonomi pendidikan. Pada bagian lain Mark Blaugh mengemukakan, "the economic of education is only part of the story of any educational issue". Menurut pandangan ini mengkaji ilmu ekonomi pendidikan maupun pembiayaan pendidikan hanya merupakan salah satu isu penting dalam dunia pendidikan.

Menurut Yahya dan Tim Dosen Administrasi Pendidikan Universitas Pendidikan Indonesia., 2012 yang dikutip oleh Mulyono pembiayaan adalah bagaimana mencari dana atau sumber dana dan bagaimana menggunakan dana itu dengan memanfaatkan rencana biaya standar, memperbesar modal kerja, dan merencanakan kebutuhan masa yang akan datang akan uang.
Sedangkan (Fattah, 2000) mendefinisikan biaya pendidikan merupakan jumlah uang yang dihasilkan dan dibelanjakan untuk berbagai keperluan penyelenggaraan pendidikan yang mencakup gaji guru, peningkatan profesional peralatan, pengadaan alat-alat dan buku pelajaran, alat tulis kantor (ATK), kegiatan ekstrakulikuler, kegiatan pengelolaan pendidikan, dan supervisi pendidikan.

Biaya merupakan suatu unsur yang menentukan dalam mekanisme penganggaran. Penentuan biaya akan mempengaruhi tingkat efisiensi dan efektivitaas kegiatan dalam suatu organisasi yang akan mencapai suatu tujuan tertentu. Kegiatan yang dilaksanakan dengan biaya yang rendah dan hasilnya mempunyai kualitas yang baik dapat dikatakan kegiatan tersebut dilaksanakan secara efisien dan efektif. Pemahaman tentang konsep pembiayaan pendidikan perlu diketahui pengertian dari tujuh konsep penting terkait dengan pembiayaan yang meliputi (1) objek biaya, (2) informasi manajemen biaya, (3) pembiayaan (financing), (4) keuangan (finance), (5) anggaran (budget), (6) biaya (cost), dan (7) pemicu biaya (cost driver).

\section{a) Objek Biaya}

Blocher dkk. mengatakan bahwa objek biaya merupakan sesuatu alumusi biaya dari berbagai aktivitas. Menurut Blocher ada empat jenis objek biaya, yakni

(1) produk atau kelompok produk yang saling berhubungan,

(2) jasa,

(3) departemen (departemen teknis, departemen sumber daya manusia), dan

(4) proyek, seperti penelitian, promosi pemasaran, atau usaha jasa komunitas.

Pendidikan sebagai suatu lembaga atau organisasi tidak berorientasi kepada laba, maka objek biayanya adalah jasa dengan seluruh elemen (perangkat keras dan lunak) yang melekat pada prosesnya.

\section{b) Informasi Manajemen Biaya}

Blocher dkk. mengatakan bahwa informasi manajemen biaya merupakan suatu konsep yang luas, yakni mencakup segala informasi yang dibutuhkan untuk mengelola secara efektif suatu perusahaan atau organisasi nonprofit, baik 
berupa informasi keuangan tentang biaya maupun informasi nonkeuangan yang ada kaitannya dengan produktivitas, kualitas, dan faktor kunci sukses lainnya untuk suatu organisasi.

\section{c) Pembiayaan (Financing)}

Pembiayaan adalah bagaimana mencari dana atau sumber dana dan bagaimana menggunakan dana itu dengan memanfaatkan rencana biaya standar, memperbesar modal kerja, dan merencanakan kebutuhan masa yang akan datang akan uang. Sementara biaya pendidikan adalah seluruh usaha yang dicurahkan oleh pemerintah dan masyarakat pendidikan berupa uang maupun non moneter, biaya memerlukan penginventarisasian yang jelas.

Financing (pembelanjaan atau pembiayaan) merupakan fungsi penyediaan dana yang diperlukan untuk melaksanakan usaha. Kebanyakan usaha besar atau kecil memerlukan dana untuk modal tetap seperti tanah, bangunan, mesin, gudang, modal kerja, dan modal tetap lainnya. Dalam usaha yang besar atau kecil modal dapat terdiri atas modal sendiri dan modal pinjaman.

\section{d) Keuangan (Finance)}

Definisi yang sederhana tentang keuangan (finance) adalah seni untuk mendapatkan alat pembayaran.

\section{e) Anggaran (Budget)}

Anggaran (budget) merupakan suatu instrumen yang dirancang untuk memfasilitasi perencanaan. Ensiklopedi Manajemen menggunakan budgeting sebagai perencanaan dan koordinasi dari berbagai kegiatan untuk mencapai suatu tujuan dalam suatu periode tertentu dengan melakukan prakiraan kebutuhan yang diperlukan dan hasil yang ingin dicapai serta pengawasan pelaksanaannya.

Knezevich mengemukakan budgeting merupakan alat penjabaran suatu rencana ke dalam bentuk biaya untuk setiap komponen kegiatan. Prosedur penganggaran dilakukan dengan (1) menyusun ramalan tentang kemungkinan pendapatan dan belanja selama periode tertentu (2) menetapkan anggaran berdasarkan ramalan, (3) statistik pelaksanaan dikumpulkan dan dibandingkan dengan dugaandugaan, (4) mengukur varian-varian dan menganalisis penyebab- penyebabnya, dan (5) melakukan perbaikan.
Menurut (Fattah, 2000)menjelaskan bahwa anggaran (budget) merupakan rencana operasional yang dinyatakan secara kuantitatif dalam bentuk satuan uang yang digunakan sebagai pedoman dalam melaksanakan kegiatan lembaga dalam kurun waktu tertentu. Oleh karena itu, di dalam anggaran tergambar kegiatan-kegiatan yang akan dilaksanakan oleh suatu lembaga.

Sebagaimana dijelaskan Yahya, faktorfaktor yang perlu dikembangkan dalam membuat anggaran adalah (1) permintaan terhadap hasil produksi dan stabilitas permintaan potensi dasar, (2) jenis-jenis hasil produksi yang dibuat, (3) jenis-jenis dan sifat hasil produksi yang dibuat, (4) kemampuan menyusun jadwal dan mengatur pelaksanaan, (5) jumlah dana yang dipergunakan dibandingkan dengan hasil yang mungkin dicapai, serta (6) perencanaan dan pengawasan.

\section{f) Biaya (Cost)}

Biaya adalah jumlah uang yang disediakan (dialokasikan) dan digunakan atau dibelanjakan untuk terlaksananya berbagai fungsi atau kegiatan guna mencapai suatu tujuan dan sasaran-sasaran dalam rangka proses manajemen. Konsep biaya secara keseluruhan berkaitan dengan setiap fungsi manajemen, yaitu (1) manajemen strategis, (2) perencanaan dan pengambilan keputusan, (3) penentuan harga pokok jasa dan pelaporan keuangan, dan (4) pengendalian manajemen dan pengendalian operasional.

\section{g) Pemicu Biaya (Cost Driver)}

Pemicu biaya (cost driver) menurut Blocher dkk. adalah faktor yang memberi dampak pada perubahan biaya total. Artinya jumlah total biaya sangat dipengaruhi oleh cost driver sebagai faktor yang mempunyai efek terhadap perubahan level biaya total dari suatu objek biaya.

\section{Pengertian Pendidikan}

Dalam (Undang-undang tentang Sistem Pendidikan Nasional No. 20, 2003) pasal 1 ayat 1, diungkapkan yang dimaksud dengan pendidikan adalah "usaha sadar dan terencana untuk mewujudkan suasana belajar dan proses pembelajaran agar peserta didik secara aktif mengembangkan potensi dirinya untuk memiliki kekuatan spiritual keagamaan, pengendalian diri, kepribadian, kecerdasan, akhlak „mulia serta 
keterampilan yang diperlukan dirinya, masyarakat, bangsa dan negara".

Jadi dapat disimpulkan bahwa pengelolaan pembiayaan pendidikan yaitu pengelolaan semua bentuk keuangan baik usaha memperoleh atau mengumpulkan modal untuk membiayai aktifitas atau kegiatan program pendidikan yang secara langsung maupun tidak langsung untuk menunjang penyelenggaraan pendidikan.

Depdiknas merumuskan tujuan manajemen keuangan pendidikan adalah sebagai berikut:

a) Memanfaatkan dana yang tersedia secara optimal berdasarkan prioritas kegiatan pendidikan yang ditetapkan.

b) Mensinergikan berbagai kegiatan antarbidang secara harmonis untuk mencapai tujuantujuan pendidikan.

c) Mengembangkan perilaku transparansi dan akuntabilitas dari pemanfaatan keuangan pendidikan sesuai dengan ketentuan perundangan yang berlaku.

Untuk mencapai tujuan tersebut, maka dibutuhkan kreativitas dalam menggali sumbersumber dana, menempatkan bendaharawan yang menguasai dalam pembukuan dan pertanggungjawaban keuangan serta memanfaatkannya secara benar sesuai peraturan perundangan yang berlaku.

Manajemen keuangan sekolah perlu memperhatikan sejumlah prinsip. (Undangundang tentang Sistem Pendidikan Nasional No. 20 , 2003) pasal 48 menyatakan bahwa pengelolaan dana pendidikan berdasarkan pada prinsip transparansi (keterbukaan sumber keuangan,jumlah, rincian penggunaan, pertanggungjawaban, dsb), akuntabilitas (dapat dipertanggung jawabkan sesuai dengan perencanaan yang telah ditetapkan), efektivitas (kualitas outcome sesuai rencana), dan efesiensi (kuantitas hasil sangat bagus perbandingan yang terbaik antara masukan/input (pikiran, waktu, dan biaya) dan keluaran/output/hasil).

\section{Pembiayaan Pendidikan Di Sekolah}

Dalam (Horngren, 1993) Sumber pendanaan pendidikan sebagaimana dinyatakan pada UU RI
No. 20 tahun 2003 tentang Sisdiknas Pasal 46 ayat (1) yaitu pendanaan pendidikan menjadi tanggung jawab bersama antara Pemerintah, Pemerintah Daerah dan masyarakat.

Pembiayaan pendidikan terbagi menjadi 2 yaitu :

\section{a. Pembiayaan pendidikan di Sekolah Swasta}

Pembiayaan Pendidikan dari Swasta : Biaya pendidikan dari swasta yang dimaksud adalah biaya yang disumbangkan masyarakat (individu, perusahaan, lembaga nonpemerintah, danlainnya) ke sekolah. Misalnya, PT Pertamina, Sampoerna Foundation memberi beasiswa bagi anak-anak berprestasi, dan sponsor lainnya.

Pembiayaan Pendidikan dari Masyarakat : Biaya pendidikan dari masyarakat meliputi: sumbangan orang tua siswa, sumbangan perusahaan/swasta, dan lainnya. Sumbangan orang tua siswa yang dimaksud adalah dana yang disumbangkan langsung ke sekolah oleh orang tua siswa atau dikenal dengan dana komite sekolah. Dana tersebut terdiri atas Sumbangan Pengembangan Institusi (SPI) dan iuran atau dana Operasional Pendidikan(DOP).

\section{b. Pembiayaan Pendidikan di Sekolah Negeri}

Pembiayaan Pendidikan dari Pemerintah Pusat : Menurut ("Undang- Undang No.22 tahun 1999 tentang otonomi daerah," n.d.), maka pengelolaan pendidikan menengah diserahkan kepada pemkab/pemkot.Aliran dana dari pusat ke daerah dilakukan melalui mekanisme dana perimbangan, khususnya melalui Dana Alokasi Umum (DAU). Menurut, ("UU No.25 tahun 1999 tentang perimbangan keuangan antara pusat dan daerah," n.d.) selain DAU, dana perimbangan yang diterima pemerintah daerah adalah dana bagi hasil dan Dana Alokasi Khusus (DAK). Sumber penerimaan daerah lainnya adalah Pendapatan Asli Daerah (PAD), dan pinjaman daerah. Semua penerimaan dan pengeluaran dalam rangka desentralisasi dicatat dan dikelola dalam APBD.

Pembiayaan Pendidikan dari Pemerintah Kabupaten/Kota: Biaya pendidikan dari pemerintah kabupaten/kota yang diterima digunakan untuk belanja administrasi umum yang terdiri dari: belanja pegawai, belanja barang dan jasa, dan pemeliharaan. Biaya dari pemkab/pemkot 
lainnya adalah dana beasiswa untuk siswa dan dana subsidi untuk penyelenggaraan ujian sekolah dan ujian nasional.

\section{DOP (Definisi Operasional Pengelolaan)}

Pengelolaan merupakan terjemahan dari kata managemen yang berasal dari bahasa Inggris dan kemudian di Indonesia menjadi manajemen. Menurut Suharsimi Arikunto dalam bukunya "Pengelolaan Kelas dan Siswa" bahwa pengelolaan adalah penyelenggaraan atau pengurusan agar suatu yang dikelola dapat berjalan dengan lancar, efektif, dan efisien.

a. Perencanaan (Planning), menentukan apa yang harus terjadi di masa depan, pembentukan rencana kegiatan.

b. Pengorganisasian (organizing), membuat terjadi penggunaan optimal sumber daya untuk mencapai sasaran.

c. Pelaksanaan (actuating), menggerakkan orang untuk mencapai tujuan yang telah ditetapkan. Pengendalian dan pemantauan (controlling, monitoring), memeriksa proses disbanding rencana, melakukan modifikasi rencana dan kegiatan selanjutnya

\section{Fungsi Pengelolaan Pembiayaan Pendidikan}

Menurut (Anwar, 1991) Pengelolaan pembiayaan pendidikan sama dengan manajemen pembiayaan, dan pengelolaan mempunyai tiga fungsi yaitu perencanaan, pelaksanaan, dan evaluasi. Dalam penelitian ini yang akan dibahas yaitu perencanaan pembiayaan pendidikan, pelaksanaan pembiayaan pendidikan dan evaluasi pembiayaan pendidikan.

\section{a. Perencanaan Pembiayaan Pendidikan}

Perencanaan adalah suatu proses mempersiapkan serangkaian keputusan untuk mengambil tindakan di masa yang akan datang diarahkan untuk tercapainya tujuan- tujuan dengan sarana yang optimal.

Pada sebuah organisasi atau lembaga apapun bentuk dan namanya, sebelum melangkah untuk mencapai tujuan, maka terlebih dahulu ada perencanaan. Perencanaan pada sebuah lembaga sangat esensial, karena pada kenyataannya, perencanaan memegang pevranan yang lebih penting dibandingkan dengan fungsi- fungsi lain.
Tanpa ada perencanaan, maka akan sulit mencapai tujuan.

Lankah-langkah dalam perencanaan yaitu Pertama, tahapan menetapkan tujuan atau serangkaian tujuan. Perencanaan dimulai dengan keputusan-keputusan. Tanpa rumusan tujuan yang jelas, sebuah lembaga akan menggunakan sumber daya yang secara tidak efektif. Kedua, merumuskan keadaan saat ini, pemahaman akan kondisi sekarang dari tujuan yang hendak dicapai sangat penting, karena tujuan dan rencana menyangkut waktu yang akan datang.

Ketiga, mengidentifikasikan segala kemudahan, kekuatan, kelemahan serta hambatan perlu diidentifikasikan untuk mengukur kemampuan dalam mencapai tujuan, oleh karena itu perlu dipahami faktor-faktor lingkungan internal dan eksternal yang dapat membantu mencapai tujuan, atau mungkin menimbulkan masalah. Keempat, mengembangkan rencana atau serangkaian kegiatan untuk mencapai tujuan tahap akhir dalam proses perencanaan meliputi pengembangan berbagai alternatif kegiatan untuk mencapai tujuan.

Perencanaan diartikan sebagai suatu proses penentuan tujuan atau sasaran yang hendak dicapai dan menetapkan jalan dan sumber-sumber yang diperlukan untuk mencapai tujuan itu seefisien dan seefektif mungkin. Perencanaan Pembiayaan Pendidikan ini mencakup kegiatan penting yaitu penyusunan Rencana Anggaran Pendapatan dan Belanja Sekolah (RAPBS) dan pengembangan Rencana Anggaran Pendapatan dan Belanja Sekolah (RAPBS). Perencanaan keuangan sekolah sedikitnya mencakup dua kegiatan yakni penyusunan anggaran dan pengembangan rencana anggaran belanja sekolah. Penganggaran merupakan proses kegiatan atau proses penyusunan anggaran (budget).

\section{b. Pelaksanaan Pembiayaan Pendidikan}

Pelaksanaan adalah suatu tindakan atau pelaksanaan dari sebuah rencana yang sudah disusun secara matang dan terperinci, implementasi biasanya dilakukan setelah perencanaan sudah dianggap siap. Secara sederhana pelaksanaan bisa diartikan 
penerapan. Majone dan Wildavsky mengemukakan pelaksanaan sebagai evaluasi. Browne dan Wildavsky mengemukakan bahwa Pelaksanaan adalah perluasan aktivitas yang saling menyesuaikan.

Setelah perencanaan pembiayaan pendidikan selesai dan disetujui oleh semua komponen yang terlibat, dan menghasilkan sebuah Rencana Anggaran Pendapatan dan Belanja Sekolah (RAPBS), tahapan manajemen selanjutnya yaitu pelaksanaan pembiayaan pendidikan. Kegiatan pelaksanaan pembiayaan madrasah meliputi dua kegiatan besar yakni penerimaan dan pengeluaran keuangan madrasah/sekolah. Kegiatan kedua dari manajemen pembiayaan adalah pembukuan atau kegiatan pengurusan keuangan. Hal-hal yang perlu dibukukan dalam keuangan sekolah adalah menyangkut penerimaan dan pengeluaran. Penerimaan dan pengeluaran keuangan sekolah dari sumbersumber dana perlu dibukukan berdasarkan prosedur pengelolaan yang selaras dengan kesepakatan yang telah disepakati, baik berupa konsep teoritis maupun peraturan pemerintah.

Kegiatan yang di lakukan berupa :

a. Penerimaan Biaya Pendidikan

b. Pengeluaran Biaya Pendidikan

\section{c. Evaluasi Pembiayaan Pendidikan}

Evaluasi pendidikan juga diartikan dengan proses untuk memberikan kualitas yaitu nilai dari kegiatan pendidikan yang telah dilaksanakan, yang mana proses tersebut berlangsung secara sistematis, berkelanjutan, terencana, dan dilaksanakan sesuai dengan prosedur.

Proses melakukan evaluasi mungkin saja berbeda sesuai persepsi teori yang dianut, ada bermacam-macam cara. Namun evaluasi harus memasukkan ketentuan dan tindakan sejalan dengan fungsi evaluasi, yaitu:

1. Memfokuskan evaluasi

2. Mendesain evaluasi

3. Mengumpulkan informasi

4. Menganalisis informasi

5. Melaporkan hasil evaluasi

6. Mengelola evaluasi dan mengevaluasi evaluasi.

Evaluasi pembiayaan pendidikan merupakan alat untuk mengukur dari melihat hasil rencana yang dicanangkan pada planning.
Memberikan imbalan kepada staff sesuai kinerja yang ditunjukkan, dan merancang serta merencanakan kembali sambil memperbaiki halhal yang belum sempurna. Evaluasi pada administrasi berarti kegiatan mengukur tingkat efektivitas kerja personal dan tingkat efisiensi penggunaan metode dan alat bantu tertentu dalam usaha mencapai tujuan. Mengamati tingkat efektivitas maksudnya menilai tindakan tindakan atau kegiatan-kegiatan yang telah dilakukan, apakah telah menghasilkan sesuatu seperti direncanakan atau sekurang- kurangnya, apakah kegiatan itu telah berjalan di atas rel yang sebenarnya dan tidak menyimpang dari perencanaan atau tujuan yang telah ditetapkan. Sedang mengamati tingkat efisiensi maksudnya menilai tindakan tindakan/ kegiatan-kegiatan yang telah dilakukan itu apakah merupakan cara yang terbaik atau paling tidak untuk mencapai hasil yang sebesar besarnya dengan resiko yang sekecil-kecilnya, yang berarti apakah cara kerja tertentu yang sudah dipergunakan mampu memberi hasil yang maksimal.

\section{SIMPULAN DAN SARAN}

Dari pemaparan di atas dapat ditarik kesimpulan yaitu pendidikan membutuhkan biaya. Pembiayaan terhadap pendidikan harus dibayar lebih mahal karena pendidikan adalah investasi. Human Capital yang berupa kemampuan dan kecakapan yang diperoleh melalui pendidikan, belajar sendiri, belajar sambil bekerja memerlukan biaya yang dikeluarkan oleh yang bersangkutan. Perolehan keterampilan dan kemampuan akan menghasilkan tingkat balik Rate of Return yang sangat tinggi terhadap penghasilan seseorang. Pendidikan adalah tanggungjawab negara dan masyarakat, tanggungjawab kita bersama, termasuk dalam hal pembiayaan. Peran masyarakat untuk menyokong biaya pendidikan sangat penting diantaranya dengan menabung yang bermanfaat untuk membiayai pendidikan.

Biaya pendidikan adalah seluruh pengeluaran baik yang berupa uang maupun bukan uang sebagai ungkapan rasa tanggung jawab semua pihak (masyarakat, orang tua, dan pemerintah) terhadap pembangunan pendidikan agar tujuan pendidikan yang dicita-citakan tercapai secara efektif dan efisien, yang harus 
terus digali dari berbagai sumber, dipelihara, dikonsolidasikan, dan ditata secara administratif.

\section{DAFTAR RUJUKAN}

Anwar, M. . (1991). Biaya Pendidikan dan Metode Penetapan Biaya Pendidikan. Mimbar Pendidikan.

Dedi Supriadi. (2004). Satuan Biaya Pendidikan Dasar dan Menengah. Bandung: Remaja Rosdakarya.

Domai, T. (2010). Manajemen Keuangan Publik. Malang: Universitas Barawijaya Press.

Fattah, N. (2000). Ekonomi dan Pembiayaan Pendidikan. Bandung: Remaja Rosdakarya.

Horngren, P. (1993). Pengantar Akutansi Manajemen Edisi 6. Jakarta: Erlangga.

Tim Dosen Administrasi Pendidikan Universitas Pendidikan Indonesia. (2012). Manajemen Pendidikan. Bandung: Alfabeta.

Undang- Undang No.22 tahun 1999 tentang otonomi daerah. (n.d.).

Undang-undang tentang Sistem Pendidikan Nasional No. 20. (2003).

UU No.25 tahun 1999 tentang perimbangan keuangan antara pusat dan daerah. (n.d.). 